\title{
Quality of Work Life, Job Satisfaction, and the Facets of the Relationship between the Two Constructs
}

\author{
Ramawickrama, J. ${ }^{1}$, H. H. D. N. P. Opatha ${ }^{1} \&$ PushpaKumari, M. D. ${ }^{1}$ \\ ${ }^{1}$ Faculty of Management Studies and Commerce, University of Sri Jayewardenepura, Sri Lanka \\ Correspondence: Ramawickrama, J., Faculty of Management Studies and Commerce, University of Sri \\ Jayewardenepura, Sri Lanka.
}

Received: February 3, 2017

Accepted: March 2, $2017 \quad$ Online Published: March 24, 2017

doi:10.5539/ibr.v10n4p167

URL: https://doi.org/10.5539/ibr.v10n4p167

\begin{abstract}
Quality of Work Life (QWL) and job satisfaction are critical concepts in the field of Human Resource Management (HRM). An intellectual puzzle was chosen by the researchers with regard to whether QWL and job satisfaction are the same or different, and if different, how they are differed. By using the desk research strategy a systematic attempt was made to solve the intellectual puzzle to a reasonable extent. Both constructs were found to be different and related. Four facets of the relationship between the two constructs were revealed: Job satisfaction being a dimension of QWL; job satisfaction not being a dimension of QWL; job satisfaction working as an antecedent of QWL; and finally job satisfaction being a consequence of QWL. Formulated synthesis is perceived as an original contribution to the concepts of QWL and job satisfaction.
\end{abstract}

Keywords: quality of work life, job satisfaction, human resource management

\section{Introduction}

Quality of Work Life is an important issue not only for the management discipline. It has been vastly discussed by different authors in the world in relation to different disciplines including education, medicine, engineering, agriculture, information technology sector and so on. Job satisfaction is a very popular concept which has applicability and relevance to any job in any field. Basically QWL and job satisfaction are two main concepts (indeed constructs) in the fields of HRM and Organizational Behaviour. Schular and Youngblood (1986) consider QWL a strategic purpose of HRM. Opatha (2009) considers QWL a strategic goal of HRM and job satisfaction as an objective of HRM. Bernadian and Russell (1993) consider QWL a critical need for creating a competitive advantage for the firm and job satisfaction a characteristic of QWL programs. As mentioned by Patil and Swadi (2014), QWL is a buzz word in the modern time.

An intellectual puzzle arose within us with regard to whether QWL and job satisfaction are the same or different, and if different, what the differences are. If both constructs are related, it is interesting to find the facets of the relationship between the two constructs. The purpose of this study is to present a new contribution to the existing knowledge of QWL and job satisfaction by creating a new synthesis that has not been done before definitely locally (in Sri Lankan context) and perhaps internationally. Our approach for the purpose is ostensibly descriptive. This study addresses the following questions:

1) What are the origin, definitions, importance, and dimensions of QWL?

2) What are the origin, definitions, importance, and dimensions of job satisfaction?

3) Are the constructs of QWL and job satisfaction the same or different?

4) Is job satisfaction a dimension of QWL?

5) Is job satisfaction not a dimension of QWL?

6) Is job satisfaction an antecedent of QWL?

7) Is job satisfaction a consequence of QWL?

\section{Method}

As this is an attempt to answer the above mentioned specific questions, a methodical review of existent literature was accomplished through the use of archival method as approved by Tranfield, Denyer and Smart (2003). 
Academic books and journals are, in general, the most useful sources of information (Sekaran \& Bougie, 2013). Published information over the past 45 years in relevant books and refereed journals which have been published in the popular data bases such as Springer link, JSTOR, SAGE journals, Wiley Online Library, Emerald Insight, Taylor and Francis Online were utilized.

Exhibit- 1. Definitions of quality of work life in chronological order

\begin{tabular}{|c|c|c|}
\hline Year & Author & Definition of quality of work life \\
\hline 1972 & $\begin{array}{l}\text { International Labors } \\
\text { Relation Conference in } \\
\text { New York }\end{array}$ & $\begin{array}{l}\text { Aims to share knowledge and initiates a coherent theory and practice on how to create } \\
\text { the conditions for a "humane working life." }\end{array}$ \\
\hline 1975 & Hackman and Oldham & Involves the satisfaction and motivation in the workplace. \\
\hline 1977 & Boisvert & $\begin{array}{l}\text { A set of beneficial consequences of working life for the individual, the organization } \\
\text { and society. }\end{array}$ \\
\hline 1979 & $\begin{array}{l}\text { American Society of } \\
\text { Training and } \\
\text { Development as cited } \\
\text { Patil and Swadi (2014) }\end{array}$ & $\begin{array}{l}\text { A process of work organization which enables its members at the levels to actively } \\
\text { participate in shaping the organization's environment, methods and outcomes. This } \\
\text { value based process is aimed towards meeting the twin goals of enhanced effectiveness } \\
\text { of organizations and improved QWL of employees. }\end{array}$ \\
\hline 1981 & Dessler & $\begin{array}{l}\text { The level to which employees are able to satisfy their personal needs not only in terms } \\
\text { of material matters but also of self-respect, contentment and an opportunity to use their } \\
\text { talents making contribution for personal growth. }\end{array}$ \\
\hline 1983 & Carlson & $\begin{array}{l}\text { Two perspectives; it is as a goal and an organizational process for } \\
\text { 1. As a goal, QWL is the commitment of any organization to work improvement: the } \\
\text { creation of more involving, satisfying and effective jobs and work environments for } \\
\text { people at all the levels of the organization. } \\
\text { 2. As a process, QWL calls for effort to realize this goal through the active } \\
\text { involvement of people throughout the organization. }\end{array}$ \\
\hline 1983 & Nadler and Lawler & $\begin{array}{l}\text { A way of thinking about people, work and organizations. Its distinctive elements are } 1 . \\
\text { A concern about the impact of work on people as well as on organizational } \\
\text { effectiveness, and 2. The idea of participation in organizational problem solving and } \\
\text { decision making. }\end{array}$ \\
\hline 1990 & Kieman and Knutson & $\begin{array}{l}\text { It means something different to each and every individual, and is likely to vary } \\
\text { according to the individual's age, career stage and/or position in the industry. }\end{array}$ \\
\hline 1993 & Bernadian and Russell & The degree to which individuals are able to satisfy their import \\
\hline 1997 & Cummings and Worley & $\begin{array}{l}\text { The way of thinking about others, work, and the organization which is concerned about } \\
\text { workers' wellbeing and organizational effectiveness. }\end{array}$ \\
\hline 2001 & $\begin{array}{l}\text { Sirgy, Efraty, Siegel and } \\
\text { Lee }\end{array}$ & $\begin{array}{l}\text { A variety of needs through resources, activities and outcomes stemming from } \\
\text { participation in the workplace. }\end{array}$ \\
\hline 2000 & Lau & $\begin{array}{l}\text { The favourable working environment that supports and promotes satisfaction by } \\
\text { providing employees with rewards, job security and career growth opportunities. }\end{array}$ \\
\hline 2011 & Nazir et al. & $\begin{array}{l}\text { A combination of strategies, procedures and ambiance related to a workplace that } \\
\text { altogether, enhance and sustain the employee satisfaction by aiming at improving work } \\
\text { conditions for the employees of the organizations. }\end{array}$ \\
\hline 2014 & Mazloumi et al. & $\begin{array}{l}\text { Attitudes of employees towards their job, especially their work outcomes including job } \\
\text { satisfaction, mental health, and safety which directly influence organizational } \\
\text { outcomes. }\end{array}$ \\
\hline 2014 & Šverko and Galić & $\begin{array}{l}\text { iployees can satisfy their important personal needs } \\
\text { rk place and experiences in the organization. }\end{array}$ \\
\hline
\end{tabular}

(Source: Literature review)

\section{Literature Review: Quality of Work Life}

\subsection{Origin of Quality of Work Life}

According to the evidence from the evolution of Human Resource Management, the concept of QWL emerges from the post-industrial revolution as a result of the contribution of certain eminent management thinkers like Robert Owen, Charls Babbage, F.W. Taylor, Elton Mayo (Patil \& Swadi, 2014). During the era, higher productivity was emphasized totally misplacing human factors at the workplace. Several examples are: due to the division of work and specialization fellow workers were socially isolated, employees faced difficulties due to the overdependence of rules and procedures at work places, people had to work more hours a day against the accepted norms, employees were kept on ad-hoc or temporary basis. Therefore, employees were suffered from work stress, health hazards, monotony, lack of general happiness etc. As a result, negative consequences were recorded including absenteeism, high turnover, fatigue, occasional sabotage, boredom, poor morale, accidents resulting from non-attention, drug addiction and alcoholism. Hence, various studies and many experiments were conducted after the 1850s. During the period of 1857-1911, Frederick W. Taylor under the application of scientific principle mentioned the best way of doing tasks. He emphasized the importance of worker training, 
maintaining wage uniformity, and focus on attaining better productivity. He, as a consultant, considered that employees work only for money. For that reason, money should be matched to the amount produced by the employee. Meanwhile, Mayo (1927 to 1940) conducted an experiment to find out the causes of the work environment on the productivity of employee. His experiment shifted the focus of human resource from increasing worker productivity to increase worker efficiency through greater work satisfaction. During this era studies of Maslow's (1954) Hierarchical need theory and McGregor (1960) theory X and theory Y and various theories developed by other researchers suggested that a positive relationship between productivity and morale exists and enhancement in human relations would accelerate both the QWL and job satisfaction. Accordingly, the concept of QWL is not a new one (Timossi et al., 2008). The early 1970s were a fertile period for research and it was attempted to clarify the definition of QWL (Martel \& Dupuis, 2006). Nadler and Lawler (1983) mentioned that it was discussed prior to 1970s. The term "Quality of Work life" was introduced by "Louis Davis" and the research papers were published in USA journals in the year 1970. The $1^{\text {st }}$ International Conference of QWL was held in Toronto in 1972. The International Council of QWL was established in 1973. Hence, the age of the concept of QWL is closer to a half century. Due to the drastic changes in the world of business such as information technology, globalization, world business competitiveness and scarcity of natural resources, organizations pay their attention highly towards the concept of QWL and many research findings have been published in different fields. In 1960, Mayo considered QWL a multifaceted concept and Walton (1975) highlighted QWL consisting of humanistic value and social responsibilities in an organization. It is an approach or a method used for improving work in an organization (Ford, 1973). Lawler (1975), Martel and Dupuis (2006), as cited in Šverko and Galićin (2014) noted that no universally accepted definition of QWL has been formulated yet, except it has to do with the well-being of employees in an organization. Therefore, different definitions could be found from different authors and the most prominent ones are categorized based on chronological order in Exhibit 1.

\subsection{Definitions of $Q W L$}

An examination of the definitions given in Exhibit 1 makes clear that the concept of QWL has been defined in different ways by different authors from different geographical settings. Showing that it is abstract concept. As per the definition given by the International Labor Relation Conference, QWL is about creating the conditions for a humane working life. Employees are human beings and therefore they need to be considered with kindness, thoughtfulness, and sympathy. Human beings should be utilized for organizational works in order to achieve organizational goals in the way that causes them as little pain or suffering as possible. According to some, it is a process that allows employees to actively participate in making decisions which affect their lives. Further, Boisvert (1977) thought about the beneficial consequences of QWL including three aspects such as individual employees, the organization and the society. The American Society of Training and Development considered that the QWL is needed to achieve twin goals including effectiveness of organization and employee improvement. As a result, it seems that some authors considered organizational perspective of QWL (Carlson, 1980; Cummings \& Worley, 1997). Other authors considered employee perspective of QWL (Nadler \& Lawler, 1983; Kiernan \& Knutson, 1990). Not only the above, but also Armstrong (2006) includes QWL as one of human resource management policies and he has mentioned that this involves increasing the sense of satisfaction of people obtained from their work by, so far as possible, reducing monotony, increasing variety, autonomy and responsibility, and avoiding placing people under too much stress. Further, Nazir et al. (2011) also mentioned the expanded role of QWL as follows "QWL is also a combination of strategies, procedures and ambiance related to workplace that altogether, enhance and sustain the employee satisfaction by aiming and improving work condition for the employees of the organizations." Opatha (2009) mentioned that the concept of QWL could be considered one of the strategic goals of Human Resource Management. It means that the concept of QWL has exceeded its boundaries not limiting to human resource management function of an organization, it works as a concept under the strategic level of an organization. Therefore, Opatha (2009) described that human resource management needs to be done legally, fairly, efficiently and effectively in order to improve QWL. Based on the above discussion three nominal definitions are presented in this paper and they are:

1. QWL is the extent to which working in the organization possesses characteristics which make the employee healthy and happy.

2. QWL is the degree of availability of features for ensuring humane working life for each employee of the organization.

3. QWL is the extent to which employees' reasonable expectations about the employment have been met. 


\subsection{Importance of Quality of Work Life}

Recently, the concept of QWL has become important in the discipline of Human Resource Management. It discusses the way of managing people within an organization. Ahmad (2013) mentioned, "Nowadays, QWL is globally drawing more attention. In modern society people spend about more than one-third of their lives at their workplaces. Hence, the eminence and importance of QWL are unparalleled and unquestionable." Further, in 2013, Yukthamarani Permarupan et al. mentioned that an effective QWL is fundamentally a tool of improving working conditions (an employee's viewpoint) and greater organizational efficiency (mainly from the employer's viewpoint). Hence, the importance of QWL is worth to be discussed through both employee and employer perspectives. Schuler and Youngblood (1986) mentioned that QWL involves both job design and work environment. Further, they highlighted followings. Due to the deficiencies of QWL, productivity slows down and decline in the quality of products occurs in the United States. They experienced that workers are demanding greater control and involvement in their jobs. Hence, they suggested, "when employees are given a chance to voice their opinions and participate in decision making, they respond favourably; their morale, self-respect, and involvement increase; and their stress level and accident decrease." Mullins (1996) also explained that improvement of QWL is an important thing because the contribution can increase towards organizational effectiveness and reduce the negative behaviour of workers. According to Opatha (2009), if the level of well-being of employees is low, there exists a low QWL. Wright and Croppanzano (2004), Warr (2005), Wright and Bonett (2007), as cited in Bora et al. (2015) QWL is important for the success of organizational objectives. They mentioned that employees' QWL experiences are directly related to a variety of desirable organizational outcomes including reduced rate of absenteeism, tardiness frequency, reducing health care costs and turnover. Accordingly, this concept is more important for efficient and effective utilization of human resources in modern organizations. Having done a massive literature review, Bora et al. (2015) concluded "a happy worker can concentrate on work and give more productivity. A skilled worker can be retained in the organization if he/she is satisfied." Hence, QWL can be considered the core constituent at the work place to enhance their satisfaction.

As a result of a high quality work life, employees have the opportunity to drive towards personal growth and development, cooperation among members and solving problems effectively. Hence, the highest productivity can be achieved when the goals of individuals are integrated with the organizational goals. Such integration may result in a high quality product. Therefore, it can be concluded that due to having a proper QWL in an organization, ultimately customers have the chance for fulfilling their demand at the optimum level.

\subsection{Dimensions of Quality of Work Life}

As an abstract construct QWL possesses less measurable and observable properties than a concrete concept. Researchers face difficulties in defining and measuring this abstract concept due to its subjective nature. For the purpose of measurement, dimensions of QWL are need to be identified. A dimension should be a specifiable aspect of a concept. First of all, it is worth to consider the theoretical understanding of QWL. Bernadian and Russell (1993), mentioned the features of QWL in a broader perspective. They are: employment conditions (safety, health, physical environment), equity of pay, benefits and other rewards, employment security, social interaction, self-esteem, democracy (participation in decision making), worker satisfaction, income adequacy, voluntary participation by employees, training provided to employees, managers and support staffs (professionals) on their new roles and responsibilities, availability of ongoing skills training, encouragement of multi-skills development and job rotation, participation by the union when relevant, and team building.

Lawler (1975) proposed four characteristics that are necessary to include in measuring QWL. They are; First of all, it must measure the important aspects of QWL. Secondly, it must also have sufficient face validity in the eyes of anyone likely to use it. Thirdly, it must be objective and consequently, verifiable without any possibility of being manipulated. Finally, it must be capable of distinguishing between individual differences within the same work environment. As cited in Royuela et al. (2008), 10 dimensions of QWL have been presented by European Commission. They are; 1. Intrinsic job quality, 2. Skills, life-long learning and career development, 3. Gender equality, 4. Health and safety at work, 5. Flexibility and security, 6. Inclusion and access to the labor market, 7. Work organization and work-life balance, 8. Social dialogue and worker involvement, 9. Diversity and non-discrimination, and 10. Overall work performance. However, the measurement process of the above 10 dimensions is somewhat vary from others because it is essential to have objective indicators of QWL rather than subjective indicators.

There are numbers of dimensions of QWL that can be found from the empirical findings that have been conducted by various scholars and Exhibit 2 lists these components. 
Exhibit 2. Dimensions of quality of work life in chronological order

\begin{tabular}{|c|c|c|c|}
\hline Year & Author \& Country & Dimension & Type of Industry \\
\hline 1975 & $\begin{array}{l}\text { Walton } \\
\text { (USA) }\end{array}$ & $\begin{array}{l}\text { 1. Adequate and fair compensation } \\
\text { 2. Safe and healthy working conditions } \\
\text { 3. Immediate opportunity to use and develop } \\
\text { human capacities } \\
\text { 4. Opportunity for continued growth and } \\
\text { security } \\
\text { 5. Social integration in the work organization } \\
\text { 6. Constitutionalism in the work organization } \\
\text { 7. Work and total life space } \\
\text { 8. Social relevance of the work life }\end{array}$ & Service Industry employees \\
\hline 1979 & $\begin{array}{l}\text { Saklani, as Cited in Bora } \\
\text { et al. (2015) } \\
\text { (India) }\end{array}$ & $\begin{array}{l}\text { 1. Adequate and fair compensation } \\
\text { 2. Fringe benefits and welfare measures } \\
\text { 3. Job security } \\
\text { 4. Physical and work environment } \\
\text { 5. Work load and job stress } \\
\text { 6. Opportunity to use and develop human } \\
\quad \text { capacity } \\
\text { 7. Opportunity for continued growth } \\
\text { 8. Human relations and social aspect of work } \\
\quad \text { life } \\
\text { 9. Participation in decision making } \\
\text { 10. Reward and penalty system } \\
\text { 11. Equity, justice and grievance handling } \\
\text { 12. Work and total life space } \\
\text { 13. Image of organization }\end{array}$ & $\begin{array}{l}\text { Managerial and non-managerial } \\
\text { categories of employees from } 24 \\
\text { different types of organizations }\end{array}$ \\
\hline 1984 & $\begin{array}{l}\text { Levine, Taylor and Davis } \\
\text { (Europe) }\end{array}$ & $\begin{array}{l}\text { 1.Respect from superior and trust on } \\
\text { employee's capability } \\
\text { 2. Change of work } \\
\text { 3. Challenge of the work } \\
\text { 4. Future development opportunities arising } \\
\text { from the current work } \\
\text { 5. Self esteem } \\
\text { 6. Scope of impacted work and life beyond } \\
\text { work itself } \\
\text { 7. Contribution towards society from the work }\end{array}$ & Insurance Sector employees \\
\hline 1984 & $\begin{array}{l}\text { Mirvis and Lawler } \\
\text { (UK) }\end{array}$ & $\begin{array}{l}\text { 1. Safe work environment } \\
\text { 2. Equitable wages } \\
\text { 3. Equal employment opportunities } \\
\text { 4. Opportunity for advancement }\end{array}$ & Corporation service employees \\
\hline 1991 & $\begin{array}{l}\text { Baba and Jamal } \\
\text { (UK) }\end{array}$ & $\begin{array}{l}\text { 1. Job satisfaction } \\
\text { 2. Job involvement } \\
\text { 3. Work role ambiguity } \\
\text { 4. Work role conflict } \\
\text { 5. Work role overload } \\
\text { 6. Job stress } \\
\text { 7. Organizational commitment } \\
\text { 8. Turn-over intention }\end{array}$ & Health sector employees \\
\hline 1998 & $\begin{array}{l}\text { Lau and Bruce } \\
\text { (US) }\end{array}$ & $\begin{array}{l}\text { 1. Job security } \\
\text { 2. Reward system } \\
\text { 3. Training } \\
\text { 4. Career development opportunities } \\
\text { 5. Participation in decision making }\end{array}$ & Manufacturing industry employees \\
\hline 2001 & $\begin{array}{l}\text { Wyatt and Wah } \\
\text { (Singapoor) }\end{array}$ & $\begin{array}{l}\text { 1. Favorable work environment } \\
\text { 2. Personal growth and autonomy } \\
\text { 3. Nature of the Job } \\
\text { 4. Stimulating opportunities and co-workers }\end{array}$ & All type of industry employees \\
\hline 2002 & $\begin{array}{l}\text { Ellis and Pompli, as Cited } \\
\text { in Bora et al. (2015) } \\
\text { (Canberra in Australia) }\end{array}$ & $\begin{array}{l}\text { 1. Poor working environment } \\
\text { 2. Resident aggression } \\
\text { 3. Work load, inability to deliver quality of care } \\
\text { preferred } \\
\text { 4. Balance of work and family } \\
\text { 5. Shift work } \\
\text { 6. Lack of involvement in decision making } \\
\text { 7. Professional isolation }\end{array}$ & Health sector employees \\
\hline
\end{tabular}




\begin{tabular}{|c|c|c|c|}
\hline & & $\begin{array}{l}\text { 8. Lack of recognition } \\
\text { 9. Poor relationship with supervisors/peers } \\
\text { 10. Role conflict } \\
\text { 11. Lack of opportunities to learn new skills }\end{array}$ & \\
\hline 2006 & $\begin{array}{l}\text { Saraji and Dargahi } \\
\text { (Tehran) }\end{array}$ & $\begin{array}{l}\text { 1. Fair pay and autonomy } \\
\text { 2. Job security } \\
\text { 3. Reward system } \\
\text { 4. Training and career advancement } \\
\text { 5. Opportunities } \\
\text { 6. Participation in decision making } \\
\text { 7. Interesting and satisfying work } \\
\text { 8. Trust in senior management } \\
\text { 9. Recognition of efforts } \\
\text { 10. Health and safety standards at work } \\
\text { 11. Balance between the time spent at work and } \\
\text { the time spent with family and friends } \\
\text { 12. Autonomy of work to be done } \\
\text { 13. Level of stress experienced at work } \\
\text { 14. Occupational health and safety at work }\end{array}$ & $\begin{array}{l}\begin{array}{l}\text { Education and health sector } \\
\text { employees }\end{array} \\
\text { em }\end{array}$ \\
\hline 2006 & $\begin{array}{l}\text { Rose, Beh, Uli, \& Idris, } \\
\text { (Malaysia) }\end{array}$ & $\begin{array}{l}\text { 1. Career satisfaction } \\
\text { 2. Career achievement } \\
\text { 3. Career balance } \\
\end{array}$ & Managers from free trade zones \\
\hline 2007 & $\begin{array}{l}\text { Rathinam and Ismail } \\
\text { (Malaysia) }\end{array}$ & $\begin{array}{l}\text { 1. Health and well-being } \\
\text { 2. Job Security } \\
\text { 3. Job Satisfaction } \\
\text { 4. Competence Development } \\
\text { 5. The balance between work and non-work life }\end{array}$ & Information Technology professions \\
\hline 2010 & $\begin{array}{l}\text { Hosseini, as Cited in Bora } \\
\text { et al. (2015) } \\
\text { (Iran) }\end{array}$ & $\begin{array}{l}\text { 1. Fair and adequate pay and benefits } \\
\text { 2. Observance of safety and health factors } \\
\text { 3. Opportunity to continued growth and security } \\
\text { of staff } \\
\text { 4. Acceptance of work organization } \\
\text { 5. Work life and social dependence of society } \\
\text { and individual life } \\
\text { 6. Governing the overall living space in the } \\
\text { environment } \\
\text { 7. Integration of social improved human } \\
\text { abilities }\end{array}$ & Insurance sector employees \\
\hline 2011 & $\begin{array}{l}\text { Al Muftah and Lafi, } \\
\text { (Quatar) }\end{array}$ & $\begin{array}{l}\text { 1. Physical } \\
\text { 2. Psychological } \\
\text { 3. Social factors }\end{array}$ & Employees in oil and gas companies \\
\hline 2012 & $\begin{array}{l}\text { Sinha C. } \\
\text { (India) }\end{array}$ & $\begin{array}{l}\text { 1. Communication } \\
\text { 2. Career development and growth } \\
\text { 3. Organizational commitment } \\
\text { 4. Emotional supervisory support } \\
\text { 5. Flexible work arrangement } \\
\text { 6. Family response culture } \\
\text { 7. Employee motivation } \\
\text { 8. Organizational culture } \\
\text { 9. Organizational support } \\
\text { 10. Job satisfaction } \\
\text { 11. Reward and benefits } \\
\text { 12. Compensation with appropriate instructions }\end{array}$ & $\begin{array}{l}\text { Middle level managers from various } \\
\text { organizations }\end{array}$ \\
\hline 2012 & $\begin{array}{l}\text { Stephen \& Dhanapal } \\
\text { (India) }\end{array}$ & $\begin{array}{l}\text { 1. Adequate and fair compensation } \\
\text { 2. Fringe benefits and welfare measures } \\
\text { 3. Job security } \\
\text { 4. Physical and work environment } \\
\text { 5. Work load and job stress } \\
\text { 6. Opportunity to use and develop human } \\
\quad \text { capacity } \\
\text { 7. Opportunity for continued growth } \\
\text { 8. Human relations and social aspect of work } \\
\text { life } \\
\text { 9. Participation in decision making } \\
\text { 10. Reward and penalty system } \\
\text { 11. Equity, justice and grievance handling } \\
\text { 12. Work and total life space }\end{array}$ & $\begin{array}{l}\text { Employers and employees in different } \\
\text { type of small scale organizations }\end{array}$ \\
\hline
\end{tabular}




\begin{tabular}{|c|c|c|c|}
\hline & & 13. Image of organization & \\
\hline 2012 & $\begin{array}{l}\text { Ayesha Tabassum } \\
\text { (Bangladesh) }\end{array}$ & $\begin{array}{l}\text { 1. Adequate and fair compensation } \\
\text { 2. Safe and healthy working condition } \\
\text { 3. Opportunity for continued growth and } \\
\text { security } \\
\text { 4. Opportunity to use and develop human } \\
\text { capacities } \\
\text { 5. Social integration in the work organization } \\
\text { 6. Constitutionalism in the work organization } \\
\text { 7. Work and total life space } \\
\text { 8. Social relevance of the work in life }\end{array}$ & Higher education sector employees \\
\hline 2013 & $\begin{array}{l}\text { Satyaraju and Balaram, as } \\
\text { Cited in Bora et al. (2015) } \\
\text { (India) }\end{array}$ & $\begin{array}{l}\text { 1.Education } \\
\text { 2. Housing } \\
\text { 3. Health } \\
\text { 4. Employment and working condition } \\
\text { 5. Income } \\
\text { 6. Clothing } \\
\text { 7. Food } \\
\text { 8. Transportation } \\
\text { 9. Communication } \\
\text { 10. Fuel and electricity } \\
\text { 11. Environment and pollution } \\
\text { 12. Recreation } \\
\text { 13. Social security and } \\
\text { 14. Habit }\end{array}$ & Employees in manufacturing sector \\
\hline 2014 & $\begin{array}{l}\text { Mazloumi et al. } \\
\text { (Iran) }\end{array}$ & $\begin{array}{l}\text { 1. General well-being } \\
\text { 2. Home-work interface } \\
\text { 3. Job satisfaction and career satisfaction } \\
\text { 4. Stress at work } \\
\text { 5. Working conditions }\end{array}$ & Transport sector (Railway) employees \\
\hline 2015 & $\begin{array}{l}\text { Swamy et al. } \\
\text { (India) }\end{array}$ & $\begin{array}{l}\text { 1. Work environment } \\
\text { 2. Organization culture and climate } \\
\text { 3. Relation and cooperation } \\
\text { 4. Training and development } \\
\text { 5. Compensation and reward } \\
\text { 6. Facilities } \\
\text { 7. Job satisfaction and job security } \\
\text { 8. Autonomy of work } \\
\text { 9. Adequacy of resources }\end{array}$ & $\begin{array}{l}\text { Employees in } \\
\text { Manufacturing SMEs }\end{array}$ \\
\hline 2015 & $\begin{array}{l}\text { Almarshad } \\
\text { (Soudi Arabia) }\end{array}$ & $\begin{array}{l}\text { 1. Stress at work } \\
\text { 2. Work occupy } \\
\text { 3. Job satisfaction and career satisfaction } \\
\text { 4. Working condition }\end{array}$ & Diverse Professionals \\
\hline
\end{tabular}

(Source: Literature review)

The dimensions which are mentioned in Exhibit 2 cover an array of studies that have been conducted worldwide. It reviews literature from the origin of QWL to present situation; from 1975 to 2015. It includes different authors in different countries of the world, diverse sets of dimensions used for different sectors of organization (it means production, service, entrepreneurial, educational, health, transportation, higher education, technical and Information Technology sector etc.), and different kinds of employee categories such as managerial and non-managerial employees who are representing different levels of the organizations. Šverko and Galić (2014) emphasized that the factors that will be encompassed depend largely on the author's purpose and theoretical perspective.

\section{Literature Review: Job Satisfaction}

\subsection{Origin of Job Satisfaction}

The concept of Job Satisfaction has widely been used in the area of Industrial Psychology and Organizational Psychology (Judge \& Church, 2000) and it has been subjected to scientific research with Hawthorn studies conducted in the early twentieth century (1924-1933). The finding is that people work for purposes other than pay was of great importance. In 1943 Maslow's hierarchy of needs laid the foundation for the concept of job satisfaction and it explained that people seek to satisfy five basic needs in life including physiological, safety, belonging, self-esteem and self-actualization needs. Several other motivational theories are also validated to consider job satisfaction such as Adam's (1965) Equity Theory, Porter and Lawler's theory (1968), Vroom's 
Theory, Hertzberg's (1968) Two-Factor theory, Lock's (1969) Discrepancy Theory and Hackman and Oldham's (1976) Job Characteristic Model.

Further, the Classical management approach and the Neo-classic management approach are important to study the origin of the concept of job satisfaction. The Classical approach is a combination of Weber's Bureaucratic management approach and Taylor's Scientific approach regarding workers as machine and economic beings. Workers are biological (human) beings who do jobs to earn money to meet their needs. Accordingly, what workers should do is to follow the instruction of managers carefully. As a result, rewards will come in the form of money at the end. To earn more money, the worker will use his/her abilities wisely. According to Hicks and Gullett (1981), quoted in Calik (2011), "The Classical theory is minimizing human needs." On the other hand, the Neo-classical approach considers that a person is not only an economic being but he is also bearing respect for others, realizing him, and wishing to advance. With reference to this theory, humans behave in relation to other humans' behaviours. While it is called social behaviour, even the ordinary worker and the boss do the same (Roethlisberger, 1996, cited in Calik, 2011). Job satisfaction is a complex, multifaceted concept. Different authors have defined it differently. However, some of the most commonly cited definitions of job satisfaction are presented in Exhibit 3.

\subsection{Definitions of Job Satisfaction}

Exhibit 3. Definitions of job satisfaction in chronological order

\begin{tabular}{lll}
\hline Year & \multicolumn{1}{c}{ Author } & \multicolumn{1}{c}{ Definition of job satisfaction } \\
\hline 1935 & Hoppock & $\begin{array}{l}\text { It is as any combination of psychological, physiological and environmental } \\
\text { circumstances that causes a person truthfully to say I am satisfied with my job. }\end{array}$ \\
\hline 1964 & Vroom & $\begin{array}{l}\text { Focuses on the role of the employee in the work place and he explained job satisfaction } \\
\text { as effective orientation on the part of individuals toward work roles which they are } \\
\text { presently occupying. }\end{array}$ \\
\hline 1976 & Lock & $\begin{array}{l}\text { The pleasurable emotional state resulting from the appraisal of one's job as achieving } \\
\text { or facilitating the achievement of one's job values. }\end{array}$ \\
\hline 1992 & Luthans & $\begin{array}{l}\text { The extent to which work outcomes meet or exceed expectations may determine the } \\
\text { level of job satisfaction. }\end{array}$ \\
\hline 2005 & Spector & Extent to which people like (satisfaction) or dislike (dis-satisfaction) their jobs. \\
\hline 2006 & Armstrong & $\begin{array}{l}\text { A general attitude towards one's job; the difference between a number of rewards } \\
\text { workers receive and the amount they believe they should receive. }\end{array}$ \\
\hline 2009 & Robbins and Judge & $\begin{array}{l}\text { Attitude and feelings people have about their work. While positive and favourable } \\
\text { attitudes towards the job indicate job satisfaction, negative and un-favourable attitudes } \\
\text { towards the job indicate job dis-satisfaction }\end{array}$ \\
\hline 2015 & Opatha & $\begin{array}{l}\text { Describes a positive feeling about a job, resulting from an evaluation of its } \\
\text { characteristics. }\end{array}$ \\
\hline
\end{tabular}

(Source: Literature review)

According to the above definitions, job satisfaction is an attitude and mainly it is the feeling component of the attitude. Also it derives from an evaluation of the job. An employee will be satisfied when her or his needs are fulfilled. In this paper we present two nominal definitions of job satisfaction as given below.

1. Job satisfaction is the degree of pleasure felt by the employee as a result of his or her evaluation of the job.

2. Job satisfaction is the magnitude to which the employee feels favourable about his/her job.

\subsection{Importance of Job Satisfaction}

Job satisfaction becomes an important concept in modern organizations when it comes to manage employees who seek psychological and physiological fulfillment throughout their lives. Actually, job satisfaction is a feeling of employees towards their work and place of work. Hence, the concept of 'Job Satisfaction' is paramount in complex areas for the accomplishment of organizational expectations as well as the employees' expectations. It will provide direct and indirect advantages to the whole society. As mentioned by Robbins (2005), there are a large number of studies conducted to investigate the impact of job satisfaction on employee productivity, citizenship behaviors, absenteeism and turnover. Therefore, Robbins (2005, p. 87) cited followings for highlighting the importance of job satisfaction.

i. Ostroff (1992); Ryan, Schmit and Johnson (1996); Harter and Schmidt (2002) and Hayes (2002) mentioned that it is a stimulate support for the original satisfaction-performance relationship. 
ii. Locke (1976); McShane (1984); Hackett and Guion ((1985); Steel and Rench (1995) found that a consistent negative relationship between satisfaction and absenteeism, but the correlation is moderate.

iii. Hom and Griffeth (1995); Griffeth, Hom and Gaertner (2000) mentioned that satisfaction is also negatively related to turnover showing a moderate correlation.

iv. Spector (1997) proved that job satisfaction must be a major determinant of an employee's organizational citizenship behavior. Satisfied employees would seem very probable to talk positively and confidently about the organization, help others and go beyond the normal expectations in their job with voluntary commitment.

v. Schneider and Bowen (1985); Tornow and Wiley (1991); Weaver (1994); Naumann and Jackson (1999); Spring (2001); Griffith (2001) indicated that satisfied employees accelerate customer satisfaction and their loyalty.

Moreover, Rain et al. (1991) declared that job satisfaction correlates with life satisfaction. In this manner the researchers can say that a person who is satisfied with life will tend to be satisfied with one's job and also a person who is satisfied with the job will tend to be satisfied with one's life. Accordingly, it is worthwhile to manage a satisfied workforce within the organization. The ultimate benefit of such a workforce is the attainment of goals of the organization.

\subsection{Dimensions of Job Satisfaction}

As the concept of QWL, job satisfaction has also a subjective nature, based on employees' job experience and expectations. Therefore, commonly used job satisfaction measures can be found in the academic literature. As mentioned by Opatha (2015) there are two approaches for measuring job satisfaction including: 1.General evaluation (job satisfaction of an individual is measured by asking a general question). 2. Specific evaluation (job satisfaction of an individual is measured by asking several questions with regard to specific dimensions of the job). Accordingly, the following Exhibit shows measurement dimensions of job satisfaction that have been most commonly used by researchers in literature.

Exhibit 4. Dimensions of job satisfaction in chronological order

\begin{tabular}{|c|c|c|}
\hline Year & Author & Dimension \\
\hline \multirow[t]{7}{*}{1961} & Yuzuk & 1. Communication \\
\hline & & 2. Hours of work \\
\hline & & 3. Fellow employees \\
\hline & & 4. Recognition \\
\hline & & 5. Work conditions \\
\hline & & 6. Supervisor \\
\hline & & 7. Other evaluation and descriptive factors \\
\hline \multirow[t]{20}{*}{1967} & Weiss et al. & Minnesota satisfaction questionnaire included: \\
\hline & & 1. Coworkers \\
\hline & & 2. Achievement \\
\hline & & 3. Activity \\
\hline & & 4. Advancement \\
\hline & & 5. Authority \\
\hline & & 6. Company policies \\
\hline & & 7. Compensation \\
\hline & & 8. Moral values \\
\hline & & 9. Creativity \\
\hline & & 10. Independence \\
\hline & & 11. Security \\
\hline & & 12. Social service \\
\hline & & 13. Social status \\
\hline & & 14. Recognition \\
\hline & & 15. Responsibility \\
\hline & & 16. Supervision-Human relations \\
\hline & & 17. Supervision-Technical \\
\hline & & 18. Variety \\
\hline & & 19. Working condition \\
\hline \multirow[t]{5}{*}{1969} & Smith & Job descriptive indexes: \\
\hline & & 1. Work itself \\
\hline & & 2. Pay \\
\hline & & 3. Promotion opportunities \\
\hline & & 4. Supervision \\
\hline
\end{tabular}




\begin{tabular}{|c|c|c|}
\hline & & 5. Co-workers \\
\hline \multirow[t]{6}{*}{1973} & Cross & 1. Firm as a whole \\
\hline & & 2. Pay \\
\hline & & 3. Promotion \\
\hline & & 4. Job itself \\
\hline & & 5. Supervisor \\
\hline & & 6. Co-workers \\
\hline \multirow{6}{*}{$\begin{array}{l}1976, \\
1980\end{array}$} & Hackman and Oldhman & Job characteristic model \\
\hline & & 1. Skill variety \\
\hline & & 2. Task identity \\
\hline & & 3. Task significance \\
\hline & & 4. Autonomy \\
\hline & & 5. Feedback \\
\hline \multirow[t]{8}{*}{1976} & Herzberg & Two Factor Theory \\
\hline & & 1.Hygine factors that extrinsically bring dissatisfaction \\
\hline & & Company policies and administration, Supervision, \\
\hline & & Interpersonal relations, work conditions, Salary, Status, and \\
\hline & & Job security. \\
\hline & & 2. Motivating factors that intrinsically motivate employees \\
\hline & & Achievement, Recognition, Work itself, Responsibility, \\
\hline & & Advancement, and Growth. \\
\hline \multirow[t]{6}{*}{1983} & Scarpello and Campbell & 1. Nature of work \\
\hline & & 2. Control over work \\
\hline & & 3. Quality of Physical environment \\
\hline & & 4. Supervisor \\
\hline & & 5. Co-worker \\
\hline & & 6. Job reward \\
\hline \multirow[t]{11}{*}{1986} & Schuler and Youngblood & 1.Sense of responsibility \\
\hline & & 2. Challenge \\
\hline & & 3. Meaningfulness \\
\hline & & 4. Self-control \\
\hline & & 5. Recognition \\
\hline & & 6. Achievement \\
\hline & & 7. Fairness or Justice \\
\hline & & 8. Security \\
\hline & & 9. Fair pay \\
\hline & & 10. Participation in decision making \\
\hline & & 11. Feed-back \\
\hline \multirow[t]{10}{*}{1987} & Khaleque and Rahman & 1. Co-workers \\
\hline & & 2. Hours \\
\hline & & 3. Work Environment \\
\hline & & 4. Recognition \\
\hline & & 5. Security \\
\hline & & 6. Desired job \\
\hline & & 7. Autonomy \\
\hline & & 8. Benefits \\
\hline & & 9. Promotion \\
\hline & & 10. Supervision \\
\hline \multirow[t]{5}{*}{2009} & Robbins and Judge & A Summation score of a number of job facets: \\
\hline & & 1. Nature of work \\
\hline & & 2. Supervision \\
\hline & & 3. Promotion opportunities \\
\hline & & 4. Relation with coworkers \\
\hline \multirow[t]{7}{*}{2015} & Opatha & Approach of 'specific evaluation' including: \\
\hline & & 1. Pay \\
\hline & & 2. Promotion opportunities \\
\hline & & 3. Peers \\
\hline & & 4. Supervision \\
\hline & & 5. Customers \\
\hline & & 6. Job duties \\
\hline
\end{tabular}

(Source: Literature review)

The above Exhibit 4 shows the dimensions of job satisfaction which have been used by different authors since 1961 to present. There are several world recognized measurement dimensions which have been used for measuring the construct of job satisfaction (including Minnesota satisfaction questionnaire, job descriptive indexes, job characteristic model and two factor theory of Herzberg etc.). 


\section{Relationship between QWL and Job Satisfaction}

QWL and job satisfaction are both abstract concepts and they are related to work and work environment of the employee working in an organization. According to the above discussion, it seems that both concepts are crucial concepts on behalf of employees' perspective as well as organizational perspective. Krueger et al. (2002) mentioned that QWL is "an umbrella term which includes many concepts." The above literature findings under topic 3.4 revealed different ways of measuring QWL and its dimensions. On the other hand, exhibit 2 shows different dimensions of QWL used by different authors. Accordingly, several researchers have embraced that the concept of job satisfaction is one of the dimensions of the construct of QWL. But some have not measured job satisfaction as a dimension of QWL. Hence, it creates a gap to clarify the nature of the relationship between both variables and whether job satisfaction is a dimension of QWL or not.

\subsection{Job Satisfaction: As a Dimension of $Q W L$}

This means that job satisfaction is a feature of QWL. Bernadian and Russell (1993) mentioned that worker satisfaction is one of the components among the characteristics of QWL. In Exhibit 2, Baba and Jamal (1991) Rathinam and Ismail (2007), Sinha, (2012), Mazloumi et al. (2014), Swamy et al. (2015), Almarshad (2015) provide evidence that they have used job satisfaction as a dimension of QWL in their studies. It can be simply mentioned that around 30 percent of the studies (in Exhibit 2) have considered job satisfaction a measure of QWL. Especially, those findings represent UK, Malaysia, India, Iran and Soudi Arabia. Except the above main evidence, some recent empirical findings are also discussed below.

Khetavath (2015) conducted a study under the topic of "An Empirical Analysis of QWL of Employees in Indian Private Sector Organizations." For the fulfillment of this study researcher has conducted a massive literature review and finally, 77 dimensions of QWL have been found from different studies. Job satisfaction is also one of the components among the selected 77 dimensions. Therefore, the researcher selected the most frequently used six dimensions for the study, including work condition and work complexity, organizational and interpersonal relations, employee involvement and commitment, growth feeling opportunities, job satisfaction and job security.

In the study "Quality of Work Life: Scale Development and Validation." conducted by Swamy et al. in 2015, QWL was considered a multidimensional construct and initially 27 important QWL components regarding the frequency of usage of them. Job satisfaction was one of these components. For the reduction of the components exploratory factor analysis was conducted and finally nine dimensions were selected. While nine dimensions together explained $82.24 \%$ of total variance, the component of job satisfaction came out as the seventh component out of 9 . Further, it contributes to a 7.59 percentage of the variance. Accordingly, it substantiates that job satisfaction is one dimension of the measurement of QWL. Kerce and Booth-Kewley (1993), cited in Martel and Dupuis in 2006, state that assessing job satisfaction is still the most commonly used method in QWL research. Providing further evidence, Sirgy et al. (2001) used job satisfaction as a new assessment tool of QWL. Lawler (1975) mentioned that job satisfaction works as a vital part of QWL. Thus, there are some evidence to claim that job satisfaction is a dimension of QWL.

\subsection{Job Satisfaction: Not as a Dimension of QWL}

This means that job satisfaction is not a feature of QWL. Several researchers have not included job satisfaction as a dimension of the construct of QWL in their researches (in Exhibit 2) including Walton (1975); Saklani (1979); Levine, Taylor and Davis (1984); Mirvis and Lawler (1984); Lau and Bruce (1998); Wyatt and Wah (2001); Ellis and Pompli (2002); Saraji and Dargahi (2006); Rose, Beh, Uli, , and Idris (2006); Hosseini and Jorjafki (2010); Al Muftah and Lafi (2011); Stephen (2012); Tabassum (2012); and Satyaraju and Balaram (2013). In around 70 percent of studies in Exhibit 2, job satisfaction has not been considered a dimension of QWL by different authors who are representing many countries in the world including USA, India, Europe, UK, Sigapoor, and Australia. Seashora (1975), Sheppard (1975) and Lawler (1975), cited in Martel and Dupuis (2006), agreed that job satisfaction should be a different construct rather than a dimension of QWL. Further, important ideas suggested by several researchers are useful here. Timososi et al. (2008) appreciated the model proposed by Walton which broadly covers basic aspects of the work situation. As the pioneer of this concept Walton did not apply job satisfaction as a dimension to measure the construct of QWL and it provided a strong evidence for this discussion.

\subsection{Job Satisfaction: As a Cause or an Antecedent of $Q W L$}

This means that job satisfaction works as an independent variable that contributes to change the behaviour of QWL. Due to the contradictory ideas towards the relationship between QWL and job satisfaction, Seashore (1975) mentioned that job satisfaction is a construct that is inseparable from QWL and it must be considered a 
cause not a consequence of QWL. Further, Sheppard (1975) also mentioned that job satisfaction must be perceived as a cause of QWL. Mejbel et al. (2013) have conducted a thorough literature review under the topic of "Drivers of Quality of Working Life." In this study QWL was the dependent variable and eight drivers were labeled as independent variables including job satisfaction.

\subsection{Job Satisfaction: As an Outcome or Consequence of $Q W L$}

This means that QWL leads to or results in job satisfaction. There is empirical evidence that QWL resulted in employees' work responses such as job satisfaction, organizational identification, job involvement, job performance, organizational turnover, job effort, intention to quit and personal alienation (Efraty \& Sirgy, 1990; Efraty et al., 1991). Quinn and Shepherd (1974), Davis and Chern (1975), Hackman and Suttle (1977), Kabanoff, (1980), Near et al. (1980), Staines (1980), Champoux (1981), Kahn (1981) and Lawler (1982), as cited in Sinha (2012), asserted that QWL is different from job satisfaction. Conversely, QWL leads to job satisfaction. Sirgy et al. (2001) emphasized that QWL has a significant impact on satisfaction in work life (job satisfaction), satisfaction in non-work life domain, and finally satisfaction with overall life. In 2010 Reddy and Reddy did a study under the topic of "QWL of employees: emerging dimensions." In this paper they have mentioned QWL as a judgment methods. Accordingly, they explain job satisfaction, job involvement, job performance, sense of competence and productivity as the judgmental indices of the construct of QWL in an organization. In 2013 Jyothi and Neelakantan conducted a study under the title of "QWL and academic dual-career couples' job satisfaction" and results revealed a significant positive relationship between dimensions of QWL and job satisfaction. Moreover, Darabi et al. (2013) did a study titled "Relationship between Quality of Work Life and Job Satisfaction" and the results point toward that if the QWL improves, the job satisfaction will also increase. Sojka (2014) conducted a study on specification of quality of work life characteristics and identified 17 characteristics of QWL. He expressed the differentiation between QWL and job satisfaction in this way: "Although there is no formal definition of QWL, industrial psychologists and management scholars agreed that it is a construct that deals with the well-being of employees and that QWL differs from job satisfaction in that job satisfaction is just one of many outcomes of QWL."

In addition to the above mentioned studies conducted, with the intention of finding the nature of the relationship between QWL and job satisfaction, Hosmani et al. (2014) also conducted a study under the topic of "Impact of QWL on job performance amongst employees of Railway in India." In their study several characteristics of QWL have been considered together with safety measures, working conditions, welfare practices, opportunities and career development. Here, job satisfaction was considered an outcome variable. It was suggested that one can determine the success of any organization based on employee satisfaction levels, one's performance, productivity and successful QWL programs.

A study of "Quality of Work Life and Job Satisfaction among Employees in Government Organizations in IRAN" conducted by Nekouei et al. (2014) showed that there is a relationship between QWL and job satisfaction. As a result, they suggested that job satisfaction could be improved in a better way by improving and promoting QWL. Moreover, Muindi et al. (2015) studied towards quality of work life, personality, job satisfaction, competence and job performance: a review of literature and emphasized that QWL is a strategy for improving employees' QWL with the objective of satisfying both organizational objectives and employee needs. Conversely, successful organizations contemplate job satisfaction to be vital for the work performance. On the other hand, they conclude that job satisfaction alone cannot lead to performance.

Hence job satisfaction must be one of the outcomes of QWL. Rai (2015) conducted a study with reference to the IT Professionals in India having the topic of "Does quality of work life have effect on job performance?" and it was found that the accomplishment of employees' needs will intensify employee satisfaction with the job, commitment to his/her job and hence leading to desire long tenure at their workplace. According to Swapna (2015), a study under the title of "Quality of Work Life Metrics as a Predictor of Job Satisfaction and Organizational Commitment" with special reference to IT industry, QWL influences job satisfaction and organizational commitment to a greater extent when compared to other industries.

\section{Conclusion}

Detailed discussion about QWL and job satisfaction uncovers that it is generally observed that both concepts are employee related concepts which are essential for the achievement of goals of a particular organization. This detailed discussion separately shows the origin, definitions, importance and dimensions of both constructs QWL and job satisfaction. Then, the discussion was directed under the sub-title "relationship between QWL and job satisfaction". Different facets of job satisfaction could be explored through the literature and those were categorized into four aspects including job satisfaction as a dimension of QWL; job satisfaction not as a dimension of QWL; job satisfaction as a cause or an antecedent factor of QWL; and job satisfaction as a 
consequence or outcome factor of QWL. As a result it reveals QWL and job satisfaction being not the same but different concepts. Of course they are related as two phenomena in managing people at work. It is possible to treat job satisfaction as an important dimension of QWL. Hence, job satisfaction is a narrower concept and QWL is a broader concept. Not only that it is possible to treat job satisfaction as an antecedent of QWL, but also job satisfaction works as a consequence or outcome factor of QWL. Furthermore, the findings reveal that many researchers have used job satisfaction as an outcome factor or consequence of QWL. Having sufficient evidences, finally, we argue that both constructs QWL and job satisfaction are not the same, but different. Further, different four facets of the relationship between the two constructs were explored. We believe that our desk research will be useful for future research studies involving QWL and job satisfaction.

\section{References}

Ahmad, S. (2013). Paradigms of quality of work life. Journal of Human Values, 19(1), 73-82. https://doi.org/10.1177/0971685812470345

Al Muftah, H., \& Lafi, H. (2011). Impact of QWL on employee satisfaction case of oil and gas industry in Qatar. Advances in Management and Applied Economics, 1(2), 107.

Almarshad, S. O. (2015). A Measurement Scale for Evaluating Quality of Work Life: Conceptualization and Empirical Validation. Trends in Applied Sciences Research, 10(3), 143. https://doi.org/10.3923/tasr.2015.143.156

Armstrong, M. (2006). A Handbook of Human resource Management Practice, (10 ${ }^{\text {th }}$ ed.), Kogan Page Publishing, London, 264.

Baba, V. V., \& Jamal, M. (1991). Reutilization of Job Context and Job Content as Related to Employee's Quality of Working Life: a study of psychiatric nurses. Journal of organizational behavior, 12, 379-386. https://doi.org/10.1002/job.4030120503

Benardin, H. J., \& Russell, J. E. (1993). Human Resource management; An Experiential Approach, (2 ${ }^{\text {nd }}$ ed.).

Boisvert, M. (1977). La qualite de vie au travail (Ecole des Hautes Etudes Commerciales, Montreal.

Bora, B., Saumendra, D., \& Murthy, V. (2015). Quality of Work Life-A Literature Review. International Journal in Management and Social Science, 3(3).

Carlson, H. C. (1983). A model of quality of work life as a developmental process. Education+ Training, 25(1), 27-32. https://doi.org/10.1108/eb016949

Celik, M. (2011). A theoretical approach to the job satisfaction. Polish journal of management studies, 4, 7-14.

Cross, D. (1973). The Worker Opinion Survey: A measure of shop-floor satisfaction. Occupational Psychology. Retrieved from http://psycnet.apa.org/psycinfo/1975-22058-001

Cummings, T. G., \& Worley, C. G. (1997). Organization change and development.

Darabi, M. et al. (2013). Relationship between Quality of Work Life and Job Satisfaction on, 3(4), 508-513.

Dessler, G. (1981). Personnel Management. Reston Publishing Company: Reston.

Ford, R. N. (1973). Job enrichment lessons from AT\&T. Harvard Business Review, 51(1), 96-106.

Hackman, J. R., \& Oldham, G. R. (1975). Development of the job diagnostic survey. Journal of Applied Psychology, 60(2), 159. https://doi.org/10.1037/h0076546

Herzberg, H. F. (1976). Motivation-Hygiene Profiles, 20.

Hoppock, R. (1935). Job satisfaction, Harper and Brother, New York.

Judge, T. A., \& Church, A. H. (2000). Job satisfaction: Research and practice. Industrial and organizational psychology: Linking theory with practice, 166-198. https://doi.org/10.1037/10519-162

Jyothi, P., \& Neelakantan, S. (2013) Quality of Work Life and Acedamic Dual-Career Couples Job Satisfaction. International Journal of General Management, 2(4).

Khaleque, A., \& Rahman, M. A. (1987). Perceived importance of job facets and overall job satisfaction of industrial workers. Human Relations, 40(7), 401-415. https://doi.org/10.1177/001872678704000701

Khetavath, P. S. (2015). An Empirical Analysis of Quality of Work Life of Employees in Indian Private Sector Organizations, International Conference on Trends in Economics, Humanities and Management

Kiernan, W. E., \& Knuston, K. (1990). Quality of work life, in R. L. Schalock and M.J. Begab (Ed.), Quality of 
Life: Perspectives and Issues. Washington, DC, US:xii American Association of Mental Retardation.

Krueger, P., Brazil, K., Lohfeld, L., Edward, H. G., Lewis, D., \& Tjam, E. (2002). Organization specific predictors of job satisfaction: findings from a Canadian multi-site quality of work life cross-sectional survey. BMC Health Services Research, 2(1), 1. https://doi.org/10.1186/1472-6963-2-6

Lau, R. S. (2000). Quality of work life and performance-An ad hoc investigation of two key elements in the service profit chain model. International Journal of Service Industry Management, 11(5), 422-437. https://doi.org/10.1108/09564230010360164

Lau, R. S., \& May, B. E. (1998). A win-win paradigm for quality of work life and business performance. Human Resource Development Quarterly, 9(3), 211-226. https://doi.org/10.1002/hrdq.3920090302

Lawler, E. E. (1975). Measuring the psychological quality of working life: The why and how of it. The quality of working life, 1, 123-133.

Levine, M. F., Taylor, J. C., \& Davis, L. E. (1984). Defining quality of working life. Human Relations, 37(1), 81-104. https://doi.org/10.1177/001872678403700105

Lock, E. A. (1976). The nature and causes of satisfaction. Handbook of industrial and organizational psychology, Chicago: Rand McNally.

Luthans, F. (1998). Organizational Behavior, ( $8^{\text {th }}$ ed.), McGraw-Hill, Irwin, Boston, 147.

Martel, J. P., \& Dupuis, G. (2006). Quality of work life: Theoretical and methodological problems, and presentation of a new model and measuring instrument. Social indicators research, 77(2), 333-368. https://doi.org/10.1007/s11205-004-5368-4

Maslow, A. (1954). Motivation and Personality, New York: Harper \& Row.

Mayo, E. (1933). The human Problems of an Industrial Civilization, New York: Macmillan chaps.3-5.

Mazloumi, A. et al. (2014). Quality of Working Life Assessment among Train Drivers in Keshesh Section of Iran Railway, 6(2), 50-55.

McGregor, D. (1960). Theory X and theory Y. Organization theory, 358-374.

Mejbel, A. E., \& Almsafir, M. (2013). The Drivers of Quality of Working Life (QWL): A Critical Review. Australian Journal of basic and Applied Sciences, 7(10), 398-405.

Mirvis, P. H., \& Lawler, E. E. (1984). Accounting for the quality of work life. Journal of Organizational Behavior, 5(3), 197-212. https://doi.org/10.1002/job.4030050304

Muindi, F., \& K'Obonyo, P. (2015). Quality of Work Life, Personality, Job satisfaction, Competence, and Job performance: A Critical Review of Literature, European Scientific Journal, 1(11), No.26 ISSN: 1857-7881 (Print) e - ISSN 1857- 7431. http://eujournal.org/index.php/esj/article/view/6243/6012

Mullins, L. J. (1996). Management and Organizational Behavior, ( $4^{\text {th }}$ ed.), London: Pitman.

Nadler, D. A., \& Lawler, E. E. (1983). Quality of work life: perspectives and directions. Organizational dynamics, 11(3), 20-30. https://doi.org/10.1016/0090-2616(83)90003-7

Nazir, U., Qureshi, T. M., Shafaat, T., \& Ilyas, A. (2011). Office harassment: A negative influence on quality of work life. African Journal of Business Management, 5(25), 10276. https://doi.org/10.5897/AJBM11.766

Nekouei, M. H., Masud, J. B., \& Ahmad, A. B. (2014). Quality of Work Life and Job Satisfaction among employee in government organizations in IRAN, 4(1), 217-229.

Opatha, H. H. D. N. P. (2009). Human Resource Management: Personnel, Department of HRM, University of Sri Jayewardenapura, Sri Lanka.

Opatha, H. H. D. N. P. (2015). Organizational Behavior: The Human Side of Work, Feather Print Service, Sri Lanka.

Patil, L., \& Swadi, S. (2014). Quality of Work Life: A Review Social Science Research Paper, 3(11), ISSN 2250-1991.

Rai, R. (2015). Does Quality of Work Life Have Effect on Job Performance? A Study on Indian IT Professionals, SIBM Pune Research Journal, X, 93-99.

Rain, J. S., Lane, I. M., \& Steiner, D. D. (1991). A current look at the job satisfaction/life satisfaction relationship: Review and future considerations. Human relations, 44(3), 287-307. 
https://doi.org/10.1177/001872679104400305

Reddy, L. M., \& Reddy, M. P. (2010). Quality of work life of employees : emerging dimensions. Asian Journal of Management Research, 1(1), 827-839.

Rethinam, G. S., \& Ismail, M. (2007). Constructs of quality of work life: A perspective of information and technology professionals. European journal of social sciences, 7(1), 58-70.

Robbins, S. P. (2005). Organizational Behavior, (11 ${ }^{\text {th }}$ d.). New York: Prentice-Hall, Inc.

Robbins, S. P., \& Judge, T. A. (2009). Organizational Behavior. (13 ${ }^{\text {th }}$ ed). Upper Saddle River: New Jersey, Pearson Prentice Hall.

Rose, R. C., Beh, L., Uli, J., \& Idris, K. (2006). Quality of work life: Implications of career dimensions. Journal of Social Sciences, 2(2), 61-67. https://doi.org/10.3844/jssp.2006.61.67

Royuela, V., López-Tamayo, J., \& Suriñach, J. (2008). The institutional vs. the academic definition of the quality of work life. What is the focus of the European Commission? Social Indicators Research, 86(3), 401-415. https://doi.org/10.1007/s11205-007-9175-6

Saraji, G. N., \& Dargahi, H. (2006). Study of quality of work life (QWL). Iranian journal of public health, 35(4), 8-14. http://citeseerx.ist.psu.edu/viewdoc/download?doi=10.1.1.603.2552\&rep=rep1\&type=pdf

Scarpello, V., \& Campbell, J. P. (1983). Job satisfaction: Are all the parts there? Personnel psychology, 36(3), 577-600. https://doi.org/10.1111/j.1744-6570.1983.tb02236.x

Seashore, S. E., \& Taber, T. D. (1975). American Behavior Scientist, 18, Sage Publication, Inc.

Sekaran, U., \& Bougie, R. (2013). Research method for business: A skill Building Approach. New York: John

Shouler, R. S., \& Youngblood, S. A. (1986). Effective Personnel Management, (2 ${ }^{\text {nd }}$ ed.), West Publishing Company.

Sinha, C. (2012). Factors affecting quality of work life: empirical evidence from Indian organizations. Australian Journal of Business and Management Research, 1(11), 31-40.

Sirgy M. J., D. Efraty, P. S., \& Dong-Jin, L. (2001). A New Measure of Quality of Work Life (QWL) Based on Need Satisfaction and Spilloover Theories. Social Indicator Research, 55(3), 241-302. https://doi.org/10.1023/A:1010986923468

Smith, P. C. (1969). The measurement of satisfaction in work and retirement: A strategy for the study of attitudes.

Sojka, L. (2014). Specification of the Quality of Work Life Characteristics. Sociologic, 46(3), 283-299.

Spector, P. E. (1997). Job satisfaction: Application, assessment, causes, and consequences (Vol. 3). Sage publications. https://doi.org/10.4135/9781452231549

Stephen, A., \& Dhanapal, D. (2012). Quality of Work Life in Small Scale Industrial Units: Employers and Employees Perspectives. European Journal of Social Sciences ISSN, 1450-2267.

Šverko, B., \& Galić, Z. (2014). The Perceived Quality of Working Life in Croatia and the European Union. Društvenaistraživanja, 23(4), 557-575. https://doi.org/10.5559/di.23.4.01

Swamy, D. R., Nanjundeswaraswamy, T. S., \& Rashmi, S. (2015). Quality of Work Life: Scale Development and Validation. IntrernationalJurnal of Caring Science, 8(2), 281.

Swapna, M. (2015). Quality of Work Life Metrics as a Predictor of Job Satisfaction and Organizational Commitment: A Study with Special Reference to Information Technology Industry, 6(3), 170-176.

Tabassum, A. (2012). Interrelations between quality of work life dimensions and faculty member job satisfaction in the Private Universities of Bangladesh. European Journal of Business and Management, 4(2), 78-89.

Timossi, L. D. S., Pedroso, B., Francisco, A. C. D., \& Pilatti, L. A. (2008). Evaluation of Quality of work life: An adaptation from the Walton's QWL model.

Tranfield, D., Denyer, D., \& Smart, P. (2003). Towards a methodology for developing evidence - informed management knowledge by means of systematic review. British Journal of Management, 14(3), 207-222. https://doi.org/10.1111/1467-8551.00375

Vroom, V. H. (1962). EGO - INVOLVEMENT, JOB SATISFACTION, AND JOB 
PERFORMANCE1. Personnel psychology, 15(2), 159-177.

https://doi.org/10.1111/j.1744-6570.1962.tb01858.x

Walton, R. E. (1975). Criteria for Quality of Working Life. In L.E. Davis, A.B. Cherns and Associates (Eds.).The Quality of Working. New York: The FreePress, Life, 1, 91-104.

Weiss, D. J., Dawis, R. V., \& England, G. W. (1967). Manual for the Minnesota Satisfaction Questionnaire. Minnesota studies in vocational rehabilitation.

Wyatt, T. A., \& Wah, C. Y. (2001). Perceptions of QWL: A study of Singaporean Employees Development. Research and Practice in Human Resource Management, 9(2), 59-76. http://citeseerx.ist.psu.edu/viewdoc/download?doi=10.1.1.730.424\&rep=rep1\&type=pdf

Yukthamarani, P. P., Almamun, A., \& Roselhna, A. S. (2013). Quality of Work Life on Employees Job Involvement and Affective Commitment between the Public and Private Sector in Malaysia. Asian Social Science, 9(7).

Yuzuk, R. P. (1961). The assessment of employee morale: A comparison of two measures (No. 99). Bureau of Business Research, College of Commerce and Administration, Ohio State University.

\section{Web Sites}

http://www.academia.edu/ Accessed on 15. 10.2016

http://www.skymark.com/resources/leaders/taylor.asp, Accessed on 11.02.2017

http://www.whatishumanresource.com/quality-of-work-life, Accessed on 20. 02.2017

https://en.wikipedia.org/wiki/Quality_of_working_life, Accessed on 15. 10.2016

https://www.researchgate.net/publication/282001506, Accessed on 01. 08.2016

www.isca.in, www.isca.me, Accessed on 01. 11.2016

www.worldcat.org/title/job-satisfaction-by-robert-hoppock/oclc/459407522, Accessed on 25. 08.2016

\section{Copyrights}

Copyright for this article is retained by the author(s), with first publication rights granted to the journal.

This is an open-access article distributed under the terms and conditions of the Creative Commons Attribution license (http://creativecommons.org/licenses/by/4.0/). 